\title{
On the Very Idea of a Just Wage (editorial)
}

In the aftermath of the 2008 financial crisis, smoldering questions about what just wages are, and whether markets are providing them, have erupted again. Some charge that unprecedented inequalities in income and wealth threaten national comity and are injustices in themselves. For others, regulation and egalitarian transfer policies are the real culprits, hampering efficiency and treading on property rights. Still others would like a world where people get what they deserve, and income and wealth come not through inheritance or social connections but effort and skill.

These are debates in the public sphere, but, of course, philosophers have discussed the nature and the possibility of a just wage for millennia. Plato, Aristotle, Thomas Aquinas, and Adam Smith-among many others-all grappled with the issue. But despite this timelessness, it seems to have new relevance now. And so this special issue of the Erasmus Journal for Philosophy and Economics (EJPE) collects 10 papers reflecting on new aspects of an old question: What is a just wage?

The origin of this special issue is an autumn 2016 seminar at the Erasmus Institute for Philosophy and Economics, where Joseph Heath presented a paper on climate change and economic growth. During dinner after the seminar, Heath told us that the paper he had presented, as well as two other ones, had difficulties finding a home because they were too long for the ordinary journal format. Since EJPE had regularly been publishing special contributions that were not your typical article, we thought it would be interesting to collaborate with Heath to publish one of his pieces. The idea then emerged to not only publish one article, but to organize an EJPE special issue on one of the papers, viz. the one on just wages. And so it happened.

We, the editors of this special issue, invited economists and philosophers to write on three questions about just wages: (1) What is a just wage? (2) Do markets generate just wages? And, (3) how should we intervene in markets to ensure that they generate just wages? In the

EDITORS' Note: Huub Brouwer and Thomas Mulligan are the editors of this special issue. As Mulligan is also a contributor to the issue, Willem van der Deijl agreed to edit his paper to prevent conflicts of interest. We would like to thank him for his editorial work on it. 
end, nine additional scholars contributed to this special issue. All their papers went through EJPE's normal process of blind peer review.

Joseph Heath kicks off this special issue by arguing that those who try to justify market outcomes read more into these outcomes than there is to find. The task of markets is to direct factors of production to their most efficient uses. It is not to reward productivity or talent, nor to divvy up the benefits of cooperation fairly. Andrew Lister raises some doubts about Heath's claim that markets do not reward talent, and argues egalitarians must discuss whether markets reward talent-on pain of making egalitarian theories less egalitarian. Thomas Christiano defends the claim that there is, pace Heath, room for thinking about fairness in markets, sketching an account of fair markets through an analogy with democracy. Peter Dietsch argues that there is less of a trade-off between equity and efficiency in markets than Heath suggests, because market outcomes are shaped by social norms. Lisa Herzog claims, against Heath, that people's moral intuitions about market outcomes should not be discarded, and proposes to rescue the notion of a just wage by reconstructing it along the lines of institutional desert that refers to the institutional design of markets.

Teun Dekker argues that, in a limited set of contexts, pay-as-youwant price mechanisms may reward people in accordance with their deserts. Thomas Mulligan homes in on a particular form on income, economic rent, identifies six settings in which rents arise, and argues that economic rents are undeserved. Peter Boettke, Rosolino Candela, and Kaitlyn Woltz point out that Heath seems to assume that markets are embedded in an institutional framework of private property and freedom of contract, and argue that different institutional structures may lead to different conclusions about the justice of market outcomes. Julia Maskivker takes up the question of whether a basic income may be a just wage, arguing that a gradated income grant is more distributively just than a basic income. Steven Sheffrin considers how tax policy can be used to make market outcomes align more closely with what people deserve. He defends the claim that there may be room for desert in tax policy at a broad, categorical level-but not at the level of individualized assessments.

There is one editorial observation we would like to share. We were struck by the number of contributors who not only discussed the concept of desert, but also made it central to their analyses. The only guidance given to our contributors was to write on one of the 
aforementioned questions, (1)-(3) (none of which refers to desert). Now, as desert scholars ourselves, we concede there may be a selection effect here. Nevertheless, we believe there is evidence that the concept of desert, and its application to distributive questions, is of increasing economic and philosophical interest.

Finally, we would like to thank several people for making this special issue possible. First, we are grateful to Joseph Heath for contributing the paper at the heart of the issue. Second, we thank the nine other contributors for their papers, and for bearing with us through several rounds of revisions. Third, we are indebted to the 19 anonymous referees who supplied our authors and us with excellent reports on the papers of this issue. Fourth, we are grateful to James Grayot for his thorough copy-editing work. Fifth, we thank Måns Abrahamson for formatting all the contributions. Sixth, and finally, we are grateful to the Erasmus Institute for Philosophy and the Faculty of Philosophy at Erasmus University Rotterdam for their continued support of EJPE.

HUUB BROUWER

TILBURG UNIVERSITY

EDITOR

$<$ h.m.brouwer@tilburguniversity.edu>

THOMAS MULLIGAN

GEORGETOWN UNIVERSITY

GUEST EDITOR

<thomas.mulligan@georgetown.edu> 